\title{
COMPLEX PROCEDURE FOR IMPLEMENTATION OF THE STRATEGY OF COMPETITIVENESS ENSURING OF UKRAINE'S AGRARIAN SECTOR
}

\author{
Oksana Haidai ${ }^{1}$, Mariia Bahorka ${ }^{2}$, Larisa Satyr ${ }^{3}$, Nataliia Bondarchuk², \\ Nataliia Yurchenko ${ }^{2}$ \\ ${ }^{1}$ Uman National University of Horticulture, 1, Instytutska Str., Uman, 20305, Ukraine \\ ${ }^{2}$ Dnipro State Agrarian and Economic University, 25, S. Efremov Str., 49600, Dnipro, Ukraine \\ ${ }^{3}$ Bila Tserkva National Agrarian University, pl. 8/1, Soborna Bila Tserkva, 09117 Ukraine
}

Received 0410 2019; accepted 20122019

The article defines the sequence of assessing the competitiveness factors of the agricultural sector (economic, international, political and legal, technological, social and natural climatic). The scientific approaches to the formation of the mechanism of the strategy realization of ensuring the competitiveness of the agrarian sector of Ukraine are substantiated. In the internal environment of such a mechanism is an interconnected complex of basic components and subordinate elements that reflect the specifics of modern market concepts in agricultural production aimed at ensuring the effective development of the agricultural sector and ensuring food security of the country. An integrated system for managing the competitiveness of the agricultural sector contributes to economic activities, improving product quality and ensuring food security. The article investigates that the agro sphere needs the state support in the reorganization of industrial and economic ties, in particular in the development of various forms of cooperation (including credit), organization of wholesale agro-food markets and the development of the agricultural market infrastructure. In such circumstances, it is essential to significantly expand the state regulatory functions, especially in terms of price regulation, in particular the support of prices for agricultural products, as well as in the strategic programming of the agricultural sector development.

The purpose of the article is to investigate and analyze the complex mechanism of implementation of the strategy of ensuring the competitiveness of the agrarian sector of Ukraine as the main task of state policy.

Keywords: competitiveness, strategy, implementation, agrarian sector, production.

JEL Codes: D41, Q13.

\section{Introduction}

At the present stage of development of Ukraine as a European state, it is extremely important for the national economy to encourage the resources of all the leading spheres and industries to ensure economic growth, and the country's access to such indicators of socio-economic development that will allow equal access to the European economic system.

Copyright (C) 2019 The Authors. Published by Vytautas Magnus University. This is an open-access article distributed under the terms of the Creative Commons Attribution-NonCommercial 4.0 (CC BY-NC 4.0) license, which permits unrestricted use, distribution, and reproduction in any medium, provided the original author and source are credited. The material cannot be used for commercial purposes. 


\section{Complex Procedure for Implementation of the Strategy of Competitiveness Ensuring of Ukraine's Agrarian Sector \\ Oksana Haidai, Mariia Bahorka, Larisa Satyr, Nataliia Bondarchuk, Nataliia Yurchenko}

The facts show that Ukraine is a state with agrarian and industrial economy. Therefore, close attention is needed to the problems of ensuring the competitiveness of the agricultural sector as a leading sector of the national economy. Today the agricultural production of Ukraine is characterized by raw material orientation, loss of signs of complexity, destruction of old and insufficient formation of new technological chains of value added. Outdated machinery and technologies do not allow agrarian producers to occupy decent competitive positions in the domestic and foreign agrarian markets. The existing conditions of farmers' activity do not allow them to overcome systemic losses and ensure sustainable development. The importance of solving the problems outlined necessitated intensive theoretical exploration and development of a strategy to ensure the competitiveness of the domestic agrarian sector, which would facilitate its effective development, successful integration into the world economic space and rationalization of state support for the aforementioned sector.

The fundamental works of the following scientists are devoted to the problems of formation and implementation of the strategy for ensuring the competitiveness of the agrarian sector: Kuzhel (2016), Koval et al. (2019), Bondar (2019), Popova et al. (2019), Prystupa, et al. (2019) and others. The issues of agrarian sector development and peculiarities of competitive position maintaining of the subjects of agrarian production on the market are researched by leading foreign scientists: Cadilhon (2003), Fearne (2003), Hughes (2003), Moustier (2003), Lechner (2017), Gatzert (2017), Sheldon (2017), Heyden (2015), Sidhu (2015), Volberda (2015).

The works of the presented authors lay the foundation for the scientific development of the agrarian sector in Ukraine. However, the importance and dynamism of such issues as the need to ensure the agrarian sector competitiveness, initiates the need to develop theoretical and methodological positions for the formation of appropriate strategies at the micro, meso and macro levels.

The methodological basis of the research is a complex of general scientific and special methods of cognition, in particular: a systematic approach; methods of observation, measurement and description; method of comparison; analytical and synthetic methods of cognition.

The purpose of the article is to investigate and analyze the complex mechanism of implementation of the strategy of ensuring the competitiveness of the agrarian sector of Ukraine as the main task of state policy.

\section{Results and Discussions}

In the current five-year period, the development of agriculture of the state is carried out within the framework of the State Target Program implementation for the development of the Ukrainian village for the period up to 2016, a number of industrybased programs, other regulatory and methodological documents aimed at forming a complete living environment in the rural sector of society and sustainable rural development. Considering the dynamics of the agricultural products, raw materials 
and food production, including per capita, it should be noted that the state is consistently ensuring food independence. In 2018, gross agricultural production increased by $13.3 \%$ compared to the previous year, including by $20.8 \%$ in agricultural enterprises, and by $5.5 \%$ in households.

In turn, the performance of the agrarian sector changes extremely dynamically, as evidenced by the comparative assessment of the main indicators of its competitiveness (Table 1).

It has been established that during the analyzed period the volume of gross agricultural products increased by EUR 1.8 billion (by 27.5\%), but compared to 2017, the indicator decreased by EUR 93.3 million (by 1.2\%). Budget financing efficiency tended to decrease (by 17\% in 2018 compared to 2013).

According to the results of economic activity in 2018, the level of profitability was $22.6 \%$, which is $7.8 \%$ less than in 2013 , but $7.1 \%$ higher than in 2017 .

Table 1. Macroeconomic indicators of Ukraine's agrarian sector competitiveness

\begin{tabular}{|c|c|c|c|c|c|c|c|}
\hline \multirow{2}{*}{ Rates } & \multicolumn{6}{|c|}{ Retrospective period, years } & \multirow{2}{*}{$\begin{array}{c}\text { Growth } \\
\text { rate, \% } \\
2018 / 2013\end{array}$} \\
\hline & 2013 & 2014 & 2015 & 2016 & 2017 & 2018 & \\
\hline $\begin{array}{l}\text { Amount of budget support for the } \\
\text { agricultural sector, EUR mln. }\end{array}$ & 162,9 & 244,2 & 267,7 & 367,2 & 212,2 & 173,9 & 106,7 \\
\hline $\begin{array}{l}\text { Budget financing efficiency, E, } \\
\text { EUR / } 1 \text { EUR of budget support }\end{array}$ & 0,6 & 0,4 & 0,4 & 0,3 & 0,5 & 0,5 & 83,0 \\
\hline $\begin{array}{l}\text { Agricultural Production Price } \\
\text { Index, } \%\end{array}$ & 130 & 113,6 & 106,8 & 97,1 & 124,3 & 154,5 & 118,8 \\
\hline $\begin{array}{l}\text { The level of production } \\
\text { profitability, } \%\end{array}$ & 24,5 & 24,7 & 22,8 & 11,7 & 21,1 & 22,6 & 92,2 \\
\hline $\begin{array}{l}\text { Capital investment into } \\
\text { agriculture, billion EUR }\end{array}$ & 0,3 & 0,4 & 0,5 & 0,5 & 0,6 & 0,9 & 316,3 \\
\hline $\begin{array}{l}\text { Export of agri-food products, } \\
\text { billion EUR }\end{array}$ & 2,6 & 3,4 & 4,8 & 4,5 & 6,6 & 6,8 & 259,4 \\
\hline $\begin{array}{l}\text { Export income per } 1 \text { ha of } \\
\text { agricultural land, EUR }\end{array}$ & 70,6 & 91,9 & 128,4 & 122,2 & 186,1 & 192,1 & 272,0 \\
\hline
\end{tabular}

Source: based on materials of the State Statistics Service of Ukraine (2018)

The analysis of the state of the main macroeconomic indicators of the agricultural sector competitiveness has made it possible to draw the following conclusions: the absolute value of the agricultural products produced has increased significantly; the agricultural producer price index was characterized as providing the coverage of production and economic costs with the acquisition of additional value. There is a positive dynamic of exported agricultural products.

The peculiarity of the country is the production in the territories in different climatic zones, which, on the one hand, requires more careful construction of the production structure; on the other hand, it gives the possibility of production 
diversification, zone specialization deepening on the basis of labor division.

The analysis revealed that political and legal factors are the most favorable opportunities for development and positive structural changes (+21). Economic factors ( -78 points) have the strongest negative impact. The negative effect of technological $(-38)$ and social $(-29)$ factors persists. There is a usual influence of natural and climatic factors (Table 2).

Table 2.Integral assessment of the influence of environmental factors on agricultural development

\begin{tabular}{|c|c|c|c|c|c|c|c|c|c|c|}
\hline \multirow[b]{2}{*}{$\begin{array}{l}\text { Orientation of } \\
\text { influence }\end{array}$} & \multicolumn{2}{|c|}{$\begin{array}{c}\text { Economic and } \\
\text { international factors }\end{array}$} & \multicolumn{2}{|c|}{$\begin{array}{l}\text { Political and } \\
\text { legal factors }\end{array}$} & \multicolumn{2}{|c|}{$\begin{array}{c}\text { Technological } \\
\text { factors }\end{array}$} & \multicolumn{2}{|c|}{$\begin{array}{l}\text { Social } \\
\text { factors }\end{array}$} & \multicolumn{2}{|c|}{$\begin{array}{l}\text { Natural and } \\
\text { climatic factors }\end{array}$} \\
\hline & + & - & + & - & + & - & + & - & + & - \\
\hline Total scores & 89 & 167 & 82 & 61 & 15 & 53 & 21 & 50 & 20 & 41 \\
\hline $\begin{array}{l}\text { Integral } \\
\text { evaluation }\end{array}$ & \multicolumn{2}{|c|}{-78} & \multicolumn{2}{|c|}{21} & \multicolumn{2}{|c|}{-38} & \multicolumn{2}{|c|}{-29} & \multicolumn{2}{|c|}{-21} \\
\hline
\end{tabular}

Source: based on materials of the State Statistics Service of Ukraine (2018)

Interacting with each other, external structural factors exacerbate the adverse effect on the agrarian system.

Unfortunately, during the short period of progressive transformations the agricultural system of the country did not manage to emerge as a balanced, flexible one with a high margin of safety against negative factors.

Therefore, negative structural transformations at all levels of the agrarian system are quite predictable. The profitability of agribusiness will decrease, the number of bankruptcies will increase, therefore, the ratio between profitable and unprofitable enterprises, between subjects of large, medium and small agribusiness will be unfavorable.

The poor proportion of agricultural enterprises' consumption and accumulation funds, as well as restrictions on credit resources, will not increase the share of hightech production. High prices for resources can lead to reduced acreage and crop production. In the livestock sector, reduced investment programs, falling of the purchasing power and a lack of liquidity can also lead to negative dynamics.

Only clear, deliberate state policy is able to overcome the crisis in a relatively short period with less losses and to restore the balance of the system. The first activities by the Ministry of Agrarian Policy and Food can be assessed as positive. It has been planned to allocate 6 million EUR for all events in 2018 (Table 3). 
Table 3.The amount of financial resources allocated by the state to the agrarian sphere of Ukraine

\begin{tabular}{|l|c|c|c|c|}
\hline $\begin{array}{c}\text { Name according to departmental and programmatic } \\
\text { classifications of state budget expenditures and } \\
\text { crediting }\end{array}$ & 2016 p. & 2017 p. & 2018 p. & $\begin{array}{c}\text { 2018 / 2017, } \\
\text { level }\end{array}$ \\
\cline { 2 - 5 } & \multicolumn{3}{|c|}{$\begin{array}{c}\text { Total and special funds, } \\
\text { million EUR }\end{array}$} \\
\hline Ministry of Agrarian Policy and Food of Ukraine & 281711,4 & 277117,7 & 283705,1 & 102,38 \\
\hline $\begin{array}{l}\text { The Administrative Office of the Ministry of Agrarian } \\
\text { Policy and Food of Ukraine }\end{array}$ & 159350,1 & 153316,1 & 162772,7 & 106,17 \\
\hline State Veterinary Service of Ukraine & 63867,3 & 74371,2 & 76094,6 & 102,32 \\
\hline State Agency of Land Resources of Ukraine & 39947,0 & 30123,8 & 26399,3 & 87,64 \\
\hline State Fisheries Agency of Ukraine & 7001,8 & 8415,1 & 8599,2 & 102,18 \\
\hline State Inspectorate of Agriculture of Ukraine & 11543,2 & 10890,5 & 9839,3 & 90,35 \\
\hline
\end{tabular}

Source: based on materials of the State Statistics Service of Ukraine (2018)

But it is important to clearly define the spectrum of financing directions, to reduce the time from decision-making to their actual implementation, to ensure rapid delivery of funds to primary producers, to work with federal and regional authorities.

Modern functioning features, difficult economic and political position of the state lead to an increase in the role of competitiveness for each domestic branch. This question is difficult due to the possibility of adverse situations occurring at several levels (macro, meso, and microlevels) both individually and in complex. At the same time, the peculiarity of competitiveness is that the adoption of management decisions is often carried out in the conditions of production management general level reduction (World Economic Forum, 2018). One of the major problems of modern agricultural production that needs to be solved is the lack of an effective procedure for implementing a strategy to ensure the agrarian sector competitiveness, which will allow to counteract the threats, to use the existing potential and, overall, to maintain a proper food security situation in Ukraine and contribute to the development of other sectors as tourism (Kvach et al, 2018; Koval et al, 2019; Lukjanova, 2019; Odinokova, 2019).

Given the strategic need to ensure the agrarian sector competitiveness, its role in the national economy functioning, it is considered that it is objective and advisable to take into account the complexity in creating such a procedure, which is due primarily to the complementarity between different components of competitiveness (resource, innovation, intellectual, market) (Popova et al, 2019).The procedure of the strategy implementation of the agricultural sector competitiveness ensuring of Ukraine is based on the development of appropriate scientific theory, concepts, strategies and tactics, conducting an adequate agricultural policy, problems systematization, the application of means and methods for ensuring the agricultural sector competitiveness (Lechner, Gatzert, 2017). 


\section{Complex Procedure for Implementation of the Strategy of Competitiveness Ensuring of Ukraine's Agrarian Sector \\ Oksana Haidai, Mariia Bahorka, Larisa Satyr, Nataliia Bondarchuk, Nataliia Yurchenko}

The subjects of agrarian production and state authorities are most often the subjects of the procedure of the strategy implementation of the agrarian sector competitiveness ensuring. The object of the procedure of the strategy implementation of the agrarian sector competitiveness ensuring in Ukraine are the economic processes of agrarian production as a whole, its individual elements and the complex of financial risks that affect the agrarian sector functioning.

The main purpose of the procedure of the strategy implementation of the agrarian sector competitiveness ensuring in Ukraine is to ensure the economic stability of agricultural production and to protect its economic interests from the effects of external and internal development and economic risks to provide effective development in the current and long-term period. In the process of the main goal realization, the procedure of the strategy implementation of the agrarian sector competitiveness ensuring in Ukraine is aimed at solving the main problems of agricultural production. One of the components of this procedure is the system of its support which includes the following subsystems of the procedure provision: resource support; regulatory and legal support; information support; methodological support; staffing; technical support (Fig. 1).

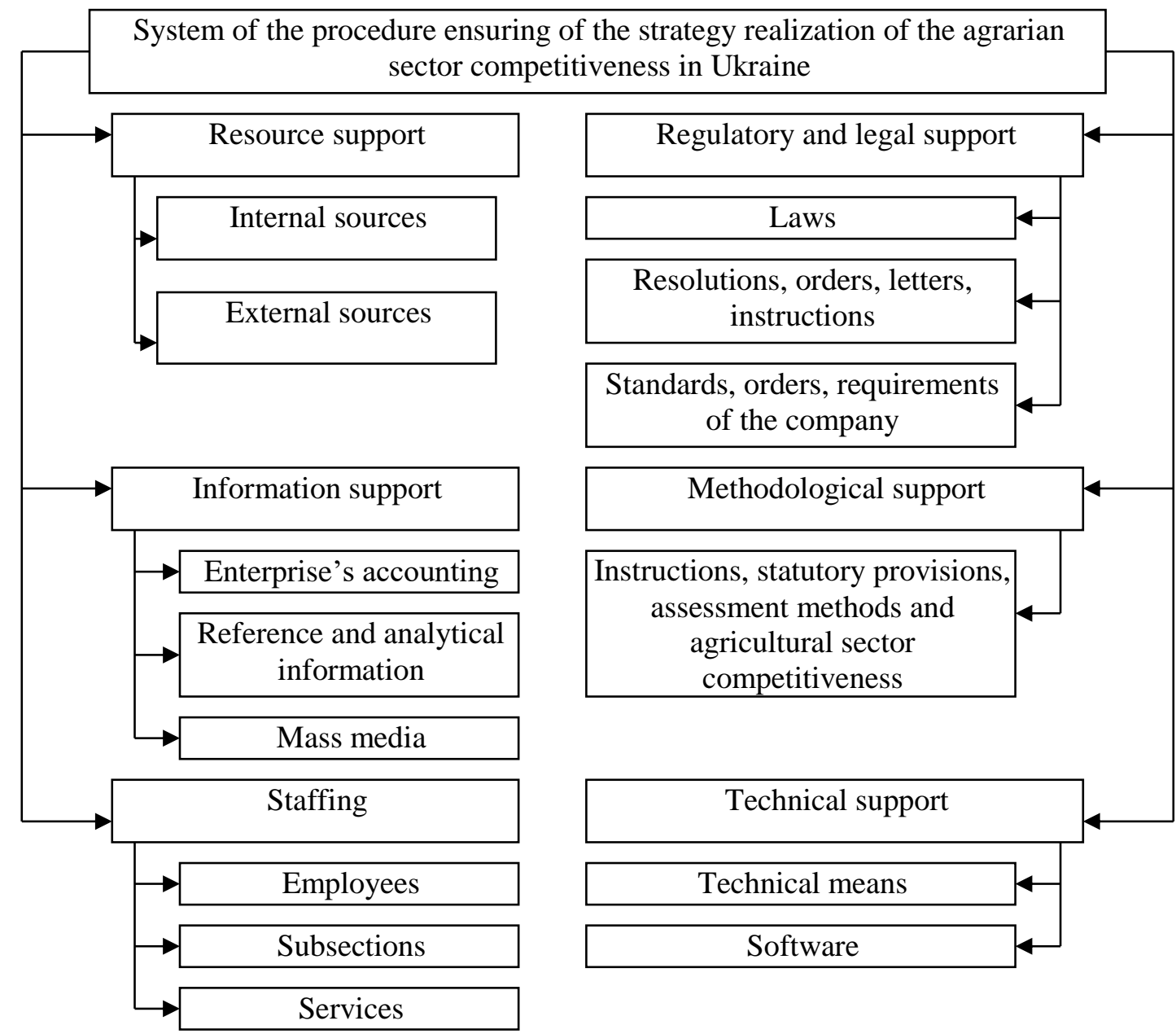

Fig. 1. The system of ensuring the procedure of the strategy implementation of the agrarian sector competitiveness in Ukraine 
The resource support of the procedure involves the formation and use of resources to meet the needs of the entity. Resource support is implemented on the basis of external and internal system of resource formation. Internal resource support is realized due to the own income of the enterprise and involves the use of such sources as retained earnings, depreciation and income from the sale of the enterprise's assets (Kropyvko, 2013).

External sources include borrowed capital, which consists of: accounts payable, short-term and long-term loans of banks, non-bank borrowed funds (state credit, loans from international financial institutions, leasing, and commercial credit).

The use of loan capital allows to substantially expand the volume of production, to provide more efficient use of own capital, to accelerate the formation of various target financial accounts, and in the result to expand the production amount (Heyden et al, 2015; Sheldon, 2017).

The basis of the methodical procedure assurance is instructions, statutory rules, assessment methods, which include the system of analytical methods allowing to characterize the agrarian sector competitiveness level in complex, taking into account internal connections and relations between the components of the agrarian sector (Cadilhon et al, 2003). The system of ensuring the procedure of the strategy implementation of the agrarian sector competitiveness the following steps: assessment of the agricultural sector competitiveness state; identification and structuring of problems and factors that influence the process of agricultural production; assessment and analysis of the agrarian sector competitiveness level of Ukraine; development of measures aimed at increasing the competitiveness level; control over the implementation of measures of the agricultural sector competitiveness assurance in today's globalized economic environment

The strategic goals of the procedure include: 1) efficient and sustainable production (development of material and technical base, increase of labor productivity, increase of resource and energy saving, elimination of resource imbalances); 2) a stable competitive market (efficient functioning of the internal market, production of competitive products, development of agro marketing, food security); 3) development of social sphere (increase of employment in rural areas, creation of special regimes of social protection in rural areas, development of social infrastructure); 4) ecological development (preservation of soil fertility, compliance with environmental safety requirements, increasing responsibility for the results of activities) (Generowicz, 2014; Gaska, K., Generowicz, 2017; Kostetska, 2018; Koval, Mikhno, 2019; Koval, Petrashevska, Popova, Mikhno, Gaska, 2019; Gubanova et al., 2019).

Due to the optimization of the agricultural sector structure, the development of transport and logistics and warehouse infrastructure, large agricultural sectors are able to reduce the cost of raw materials and resources per unit of finished products and to increase the economic efficiency of activity. The innovation process determines the need of agrarian producers in modern high-performance equipment, the use of innovative technologies, which allows to increase productivity and income 
from production and economic activity. With the use of agricultural technologies in the agricultural sphere, the improvement of the material and technical basis of agricultural commodity producers, the advantages of the large agricultural sector in comparison with the small ones are increasing.

Foreign and Ukrainian experience in the development of the agrarian sector shows that the basis for achieving the goals of the state agrarian policy are large agroindustrial enterprises and their associations, which are able to achieve high level of labor productivity and ensure efficient use of all kinds of resources. This view is also supported by some economists (Mityay et al, 2015), who point to the advantages of small-scale production over large one.

For the socio-economic conditions of Ukraine the most appropriate is implementation of the model of agribusiness organization, based on the priority of large agricultural industries of various organizational and legal forms and a clear definition of the role of small forms of farming in the countryside in the structure of a multifaceted agrarian sector. The main task of the state policy is to create an organizational and economic procedure for the implementation of relations in the agricultural market, which, firstly, guarantees the economical and efficient use of agricultural land, and secondly, guarantees compliance of the interests of all market participants, regardless of the form of ownership and management (Prystupa et al, 2019).

It should be noted that there is the need for state aid to agricultural producers in the choice of legal forms of economic management, which most closely meet the requirements of the agrarian market, as well as the tasks of the agrarian sector development and the needs of the state and society. It is advisable to provide state support for the development and distribution of modern forms of cooperation associations of small producers (farms), by assisting such associations in the acquisition of material and technical resources, obtaining loans, etc.

\section{Conclusions}

Having considered theoretical approaches to determining the factors which affect the agricultural sector development and based on a systematic approach to the identification of factors and conditions which affect the development of the agricultural sector, their structuring has been made. It allows to determine the nature of the external and internal environment on agricultural production, forecast the risks caused by the destructive influence of socio-ecological-economic processes, as well as substantiate the strategic priorities and directions of the agrarian sector development in Ukraine.

The processes of horizontal and vertical integration of agrarian producers, in particular with processing enterprises, trade and marketing organizations and financial and credit institutions into agro-food associations of different types play an important role in the development of the agrarian sector and changing the agrarian market structure. Such integrated entities can become the most stable and efficient 
production and economic structures in modern conditions. They make it possible to overcome price disparity through the use of an internal transfer price mechanism, reduce the risk of non-payment through centralized mutual account management, ensure a fair distribution of jointly generated profits, and gain additional benefits from the concentration of capital, production resources and infrastructure.

The agro sphere needs the state support in the reorganization of industrial and economic ties, in particular in the development of various forms of cooperation (including credit), organization of wholesale agro-food markets and the development of the agricultural market infrastructure.

In such circumstances, it is essential to significantly expand the state regulatory functions, especially in terms of price regulation, in particular the support of prices for agricultural products, as well as in the strategic programming of the agricultural sector development.

The most important regulatory influence of the state is in the processes of agrofood markets transformation. They are nowadays characterized with lack of developed marketing strategy of most agricultural producers; insufficient information support of consumers and sellers regarding the supply and demand for agricultural products; the lack of a mechanism for balancing supply and demand in agro food markets at all levels.

The state support of integration and concentration processes in the agricultural service, warehousing, transport and logistical support of the agricultural sector, agricultural products processing and the final product sale to the consumer, which leads to the unification of producers and makes it possible to overcome the negative effects of agricultural sphere, is also necessary.

\section{References}

Cadilhon, J.-J., Fearne, A. P., Hughes, D. R., \& Moustier, P. (2003). Wholesale markets and Food Distribution in Europe: New Strategies for Old Functions. Discussion Paper, 2. Centre for Food Chain Research, Imperial College London.

Gaska, K., \& Generowicz, A. (2017). Advanced computational methods in componentoriented modeling of municipal solid waste incineration processes // Architecture Civil Engineering Environment, 1, 117 - 130,

Generowicz, A. (2014). Multi - criteria analysis of waste management in Szczecin // Polish Journal of Environmental Studies, 23 (1), 57-63.

Gubanova, E., Kupinets, L., Deforzh, H., Koval, V., \& Gaska, K. (2019). Recycling of polymer waste in the context of developing circular economy // Architecture Civil Engineering Environment, 12(4), 99-108.

Heyden, M. L. M., Sidhu, J. S., \& Volberda, H. W. (2015). The Conjoint Influence of Top and Middle Management Characteristics on Management Innovation // Journal of Management, 44(4), 1505-1529.

Kostetska, K. (2018). Trends of development of administrative management of recreational and tourist nature production in domestic and international practice // Economics. Ecology. Socium, $2(1), 111-121$.

Koval, V., \& Mikhno, I. (2019). Ecological sustainability preservation of national economy 


\section{Complex Procedure for Implementation of the Strategy of Competitiveness Ensuring of Ukraine's Agrarian Sector \\ Oksana Haidai, Mariia Bahorka, Larisa Satyr, Nataliia Bondarchuk, Nataliia Yurchenko}

by waste management methods // Economics. Ecology. Socium, 3 (2), 30-40.

Koval, V., Mykhno, Y., Antonova, L., Plekhanov, D., \& Bondar, V. (2019). Analysis of environmental factors' effect on the development of tourism // Journal of Geology, Geography and Geoecology, 28(3), 445-456.

Koval, V., Petrashevska, A., Popova, O., Mikhno, I., \& Gaska, K. (2019). Methodology of ecodiagnostics on the example of rural areas // Architecture Civil Engineering Environment, 12(1), 139-144.

Kvach, Y., Koval, V., \& Hrymaliuk, A. (2018). Tourism and hospitality industry in the context of global economic development // Economics. Ecology. Socium, 2 (4), 11-21.

Lechner, P., \& Gatzert, N. (2017). Determinants and Value of Enterprise Risk Management: Empirical Evidence from Germany // European Journal of Finance, 24(10), 867-887. doi: https://doi.org/10.1080/1351847X.2017.1347100

Lukjanova, J. (2019). Problems and Trends of Regional Tourism Development in Latvia // Economics. Ecology. Socium, 3 (1), 1-11.

Mityay, O. \& Lagodiienko, V., Safonov V. (2015). Competitiveness of agriculture enterprises as the main factor of sustainable development of agricultural sphere // Economic AnnalsXXI, № 11-12, 59-62.

Odinokova, T. (2019). Tourism cluster as a form of innovation activity // Economics. Ecology. Socium, 3 (2), 1-11.

Popova, O., Koval, V., Antonova, L., \& Orel, A. (2019). Corporate social responsibility of agricultural enterprises according to their economic status // Management Theory and Studies for Rural Business and Infrastructure Development, 41(2), 277-289.

Prystupa L., Koval, V, Kvach, I. \& Hrymalyuk, A. (2019). Transformation of cycles of state regulation in international trade // AEBMR-Advances in Economics Business and Management Research, 95, 277-280.

Sheldon, I. (2017). The competitiveness of agricultural product and input markets: A review and synthesis of recent research //Journal of Agricultural and Applied Economics, 49(1), 1-44.

The State Statistics Service of Ukraine (2018). The program structure of the agricultural sector for the period until 2020. The official site of the Ministry of Agrarian Policy. Retrieved from: http://minagro.gov.ua/apk?nid=10516.

World Economic Forum. (2018). Global competitiveness report 2017-2018. Retrieved from http://www3.weforum.org/docs/WEF_GlobalCompetitivenessReport_2017-18.pdf. 